\title{
The relationship between pregnancy weight gain and birth weight of new born
}

\author{
Bharat Kumar Bilwal, Apurva Garg*
}

Department of Obstetrics and Gynecology, RNT Medical College, Udaipur, Rajasthan, India

Received: 25 April 2019

Accepted: 06 May 2019

\section{*Correspondence:}

Dr. Apurva Garg,

E-mail: apurvagarg89@gmail.com

Copyright: () the author(s), publisher and licensee Medip Academy. This is an open-access article distributed under the terms of the Creative Commons Attribution Non-Commercial License, which permits unrestricted non-commercial use, distribution, and reproduction in any medium, provided the original work is properly cited.

\begin{abstract}
Background: Maternal weight gain is one of the most important independent predictors of infant birth weight. It is stated that under nutrition during pregnancy and low birth weight increase the risk for diabetes and cardiovascular disease in adulthood. Normal weight gain of pregnancy $11 \mathrm{~kg}$ weight gain should be according to pre-pregnancy BMI. Patients with BMI $>25$ should gain weight of $7 \mathrm{~kg}$ patient with normal BMI should gain $11 \mathrm{~kg}$ weights.

Methods: This is a hospital based prospective study and was conducted in the Department of Obstetrics and Gynaecology, RNT Medical college Udaipur from November 2018 to March 2019 to find association between maternal weight gain and birth weight. Exclusion criteria included congenital malformations, multiple pregnancy, polyhydraminos, preeclampsia, diabetes, cardiovascular, kidney disease, RH negative pregnancy. Results were calculated by percentage.

Results: excessive weight gain during pregnancy increases baby weight. Out of total 100 cases, $88(88 \%)$ cases are Hindus and $12(12 \%)$ cases are Muslims. Out of total 100 cases 72 cases (72\%) belong to urban, 28 (28\%) belong to Rural area. Out of 100 patients 32 patients gain weight less than $11 \mathrm{~kg}$ among which 16 newborn have weight less than $2.5 \mathrm{~kg}, 68$ patients have weight gain more than $11 \mathrm{~kg}$ and 67 have baby weight more than $2.5 \mathrm{~kg}$.

Conclusions: Excessive maternal weight gain during pregnancy increases birth weight. In view of the apparent association between high birth weight and adult adiposity, an advantageous time to initiate obesity prevention efforts may be during pregnancy.
\end{abstract}

Keywords: Anemia, Birth weight, Low birth weight, Maternal weight gain

\section{INTRODUCTION}

Birth weight is an important determinant of infant's well being as low birth weight is known to increase the risk adult onset of diseases like type- 2 diabetes and ischemic heart disease. ${ }^{1}$ Maternal weight gain is one of the most important independent predictors of infant birth weight. ${ }^{2}$ It is stated that under nutrition during pregnancy and low birth weight increase the risk for diabetes and cardiovascular disease in adulthood according to Barker et al. ${ }^{3}$ As there is a rising prevalence of obesity, a variant of the original Barker hypothesis has been formulated, wherein over nutrition during pregnancy and high birth weight may cause obesity and related conditions in adulthood. ${ }^{4}$ According to this concept, excessive maternal body weight or weight gain in pregnancy perturbs the intrauterine environment during fetal development, producing permanent changes in the hypothalamus, pancreatic islet cells, adipose tissue or other biological systems that regulate body weight..$^{5}$ This study was conducted to observe the total weight gained by the pregnant women and the correlation between the weights gained by them with the birth weight of their infants. The aim of our study is to examine the associations between maternal weight gain, as a measure of over nutrition during pregnancy, and birth weight. Hence it serves to 
reduce or eliminate potential confounding by genetic, socio demographic and other individual characteristics.

Objective of this study was to observe the relationship between maternal weight gain and birth weight of newborn.

\section{METHODS}

This is a hospital based prospective study and was conducted in the Department of Obstetrics and Gynaecology, RNT Medical College Udaipur from November 2018 to March 2019 to find association between maternal weight gain and birth weight.

The subjects were taken from antenatal clinic after a detailed history and physical examination investigations, USG and were followed till delivery. The information was recorded on the basis of age, parity, education, urban/rural, status of subjects.

A total of 100 pregnant women with gestational age $>37$ weeks without any risk factors.

Total pregnancy weight gain was estimated by subtracting weight at 12 weeks from last measured weight before delivery. Results were calculated by percentage.

\section{Inclusion criteria}

- $\quad$ Full term pregnancy (>37 weeks).

\section{Exclusion criteria}

- Included congenital malformations, multiple pregnancy, polyhydraminos, preeclampsia, pre-term, diabetes, cardiovascular, kidney disease, $\mathrm{RH}$ negative pregnancy.

\section{RESULTS}

Out of total 100 cases, $88(88 \%)$ cases are Hindus and 12 (12\%) cases are Muslims (Table 1).
Table 1: Distribution of cases according to religion.

\begin{tabular}{|lll|}
\hline Religion & Number of patient & Percentage \\
\hline Hindu & 88 & $88.0 \%$ \\
\hline Muslim & 12 & $12.0 \%$ \\
\hline Total & $\mathbf{1 0 0}$ & $\mathbf{1 0 0 \%}$ \\
\hline
\end{tabular}

This preponderance was obvious because of dominance of Hindu population in this part of the country. This distribution is also because of high ratio of Hindu/ Muslims in this area.

The Table 1 shows distribution of cases according to their residence.

Table 2: Distribution of cases according to residence.

\begin{tabular}{|lll|}
\hline Residence & Number of patient & Percentage \\
\hline Rural & 28 & 28 \\
\hline Urban & 72 & 72 \\
\hline Total & $\mathbf{1 0 0}$ & $\mathbf{1 0 0 \%}$ \\
\hline
\end{tabular}

Out of total 100 cases 72 cases (72\%) belong to urban, 28 (28\%) belong to Rural area (Table 2).

Maximum cases were belongs to urban area. This study done at tertiary care center and we exclude any high risk factor like anemia. So studied population more belongs to urban area.

Table 3: Distribution of cases according to literacy.

\begin{tabular}{|lll|}
\hline Literacy & Number of patient & Percentage \\
\hline Illiterate & 22 & 22 \\
\hline Literate & 78 & 78 \\
\hline Total & $\mathbf{1 0 0}$ & $\mathbf{1 0 0 \%}$ \\
\hline
\end{tabular}

Out of 100 total cases $78(78 \%)$ are literate, $22(22 \%)$ are illiterate. The high literacy rate is due to the fact that $72.8 \%$ patients were from urban areas and also that there has been an increase in awareness regarding girl education (Table 3). People are more educated now. They give more attention to girl's education.

Table 4: Distribution of cases according to maternal age groups and the relationship between maternal weight gain and birth weight of newborn.

\begin{tabular}{|c|c|c|c|c|c|c|c|}
\hline $\begin{array}{l}\text { Age of } \\
\text { mother }\end{array}$ & $\begin{array}{l}\text { Total } \\
\text { number of } \\
\text { patients }\end{array}$ & $\begin{array}{l}\text { Maternal } \\
\text { weight gain } \\
<11 \mathrm{~kg} \\
\text { (group A) }\end{array}$ & $\begin{array}{l}\text { Birth weight } \\
\text { of new born } \\
\text { in group A } \\
<2.5 \mathrm{~kg}\end{array}$ & $\begin{array}{l}\text { Birth weight } \\
\text { of new born } \\
\text { in group A } \\
>2.5 \mathrm{~kg}\end{array}$ & $\begin{array}{l}\text { Maternal } \\
\text { weight } \\
\text { gain>11kg } \\
\text { (group B) }\end{array}$ & $\begin{array}{l}\text { Birth weight } \\
\text { of newborn } \\
\text { in group } \\
B<2.5 \mathrm{~kg}\end{array}$ & $\begin{array}{l}\text { Birth weight } \\
\text { of newborn } \\
\text { in group } \\
\text { B }>2.5 \mathrm{~kg}\end{array}$ \\
\hline $15-20$ & 9 & 5 & 4 & 1 & 4 & 0 & 4 \\
\hline $21-25$ & 52 & 17 & 8 & 9 & 35 & 1 & 34 \\
\hline $26-30$ & 33 & 7 & 2 & 5 & 26 & 0 & 26 \\
\hline $31-35$ & 5 & 2 & 2 & 0 & 3 & 0 & 3 \\
\hline$>36$ & 1 & 1 & 0 & 1 & 0 & 0 & 0 \\
\hline Total & 100 & 32 & 16 & 16 & 68 & 1 & 67 \\
\hline
\end{tabular}


According to Table 4, total 100 patients were taken. Out of these 9 patients were from age group 15-20 years and 5 out of these gained weight $<11 \mathrm{~kg}$. Out of these 5 patients, 4 patients delivered $<2.5 \mathrm{~kg}$ and only 1 patient had weight $>2.5 \mathrm{~kg}$. Maximum numbers were from age group 21-25 years. Among these 17 patients gained $<11 \mathrm{~kg}$. Out of these 17,8 patients delivered newborn $<2.5 \mathrm{~kg}$ and 9 had weight $>2.5 \mathrm{~kg}$.

35 patients gained weight $>11 \mathrm{~kg}$ out of these 35,1 patient delivered newborn having birth weight $<2.5 \mathrm{~kg}$ and 34 patients delivered newborn $>2.5 \mathrm{~kg}$.

Total number of patients in the age group 26-30 years is 33 and out of these 33,7 patients gained weight $<11 \mathrm{~kg}$. Out of these 7 patients 2 patients delivered newborn $<2.5 \mathrm{~kg}$ and 5 delivered newborn $>2.5 \mathrm{~kg}$.

In the age group 31-35 years number of patients was 5 . Out of these 5, 2 patients gained weight $<11 \mathrm{~kg}$ and birth weight of newborn was $<2.5 \mathrm{~kg}$.

3 patients gained weight $>11 \mathrm{~kg}$ and birth weight of newborn was $>2.5 \mathrm{~kg}$.

In the present study there was only one patient in the age group of $>36$ years and she gained weight $<11 \mathrm{~kg}$ and the weight of newborn was $2.5 \mathrm{~kg}$.

\section{DISCUSSION}

According to religion, $88 \%$ of our cases were Hindu and rests were Muslims. This preponderance was obvious because of dominance of Hindu population in this part of the country. This also corresponds to the census 2001 .

Most of the women (78 percent) were literate and 22 percent were illiterate. The high literacy rate is due to the fact that $72.8 \%$ patients were from urban areas and also that there has been an increase in awareness regarding girl education. 72.8 percent women were residing in urban areas and 27.2 percent were from rural areas.

Total 100 patients were taken. Out of these 9 patients were from age group 15-20 years and 5 out of these gained weight $<11 \mathrm{~kg}$. Out of these 5 patients, 4 patients delivered $<2.5 \mathrm{~kg}$ and only 1 patient had weight $>2.5 \mathrm{~kg}$. Maximum numbers were from age group 21-25 years. Among these 17 patients gained $<11 \mathrm{~kg}$. Out of these 17 , 8 patients delivered newborn $<2.5 \mathrm{~kg}$ and 9 had weight $>2.5 \mathrm{~kg}$ similar study done by Laurence et al, showed that increase weight gain during pregnancy increases maternal newborn weight. ${ }^{6}$ While study done by Maduguari et al showed that there is no relation between maternal weight gain and newborn weight. ${ }^{7}$

Total number of patients in the age group 26-30 years is 33 and out of these 33,7 patients gained weight $<11 \mathrm{~kg}$. Out of these 7 patients 2 patients delivered newborn $<2.5 \mathrm{~kg}$ and 5 deliver with our study.
Ota et al, and Yang et al, found the same result with our study. The age group 31-35 years number of patients was 5 . Out of these 5,2 patients gained weight $<11 \mathrm{~kg}$ and birth weight of newborn was $<2$ years.

In the present study there was only one patient in the age group of $>36$ years and she gained weight $<11 \mathrm{~kg}$ and the weight of newborn was $2.5 \mathrm{~kg}$.

High birth weight may also increase risk for other diseases later in life, including asthma, atopy and cancer. ${ }^{8}$

Because high birth weight predicts BMI later in life, these findings suggest that excessive pregnancy weight gain may increase the long-term risk for obesity-related disease in the offspring. ${ }^{9,10}$

\section{CONCLUSION}

Our findings suggest that excessive maternal weight gain during pregnancy increases birth weight. In view of the apparent association between high birth weight and adult adiposity, an advantageous time to initiate obesity prevention efforts may be during pregnancy.

Funding: No funding sources

Conflict of interest: None declared

Ethical approval: The study was approved by the Institutional Ethics Committee

\section{REFERENCES}

1. Barker DJ, Gluckman PD, Godfrey KM, Harding JE, Owens JA, Robinson JS. Fetal nutrition and cardiovascular disease in adult life. Lancet. 1993;341:938-41.

2. Barker DJ, Osmond C, Forsen TJ, Kajantie E, Eriksson JG. Trajectories of growth among who have coronary events as adults. N Engl J Med. 1994:9359.

3. Hales CN, Barker DJ. Type 2 (non-insulindependent) diabetes mellitus: the thrifty phenotype hypothesis. Diabetologia. 1992;35:595-601.

4. Ebbeling CB, Pawlak DB, Ludwig DS. Childhood obesity: public-health crisis, common sense cure. Lancet. 2002;360:473-82.

5. Barker DJ. Obesity and early life. Obes Rev. 2007;8:24-5.

6. Larsen CE, Serdula MK, Sullivan KM. Macrosomia: Influence of maternal overweight among a lowincome population. Am J Obstet Gynecol. 1990;162:490-4.

7. Ahmadu BU, Gofama MM, Ashir GM, Ayub-Enioa AA, Abdulrahman M, Ambe JP. The effect of maternal pregnancy body mass index as a measure of pregnancy weight gain on neonatal birth weight in Maiduguri metropolitan council of Borno state, Nigeria. Greener J Med Sci. 2012;2:168-72. 
8. Pettitt DJ, Jovanovic L. Birth weight as a predictor of type 2 diabetes mellitus: the U-shaped curve. Curr Diab Rep. 2001;1:78-81.

9. Whitaker RC, Dietz WH. Role of the prenatal environment in the development of obesity. J Pediatr. 1998;132:768-76.

10. Eriksson M, Wedel H, Wallander MA. The impact of birth weight on prostate cancer incidence and mortality in a population-based study of men born in
1913 and followed up from 50 to 85 years of age. Prostate. 2007;67:1247-54.

Cite this article as: Bilwal BK, Garg A. The relationship between pregnancy weight gain and birth weight of new born. Int J Reprod Contracept Obstet Gynecol 2019;8:2159-62. 